\title{
KINETIC STUDIES OF EXTRACELLULAR $\alpha$ - GALACTOSIDASE FROM CITROBACTER FREUNDII
}

\author{
M.A. LOKUGE and C. DEEPAL MATHEW* \\ Department of Biochemistry \& Molecular Biology, Faculty of Medicine, University of Colombo, \\ Colombo
}

(Received: 29 December 1999 ; accepted: 24 January 2002)

\begin{abstract}
Extracellular a-galactosidase producing bacteria were isolated from soil. Bacteria that showed a-galactosidase activity were identified as Escherichia coli, Klebsiella pneumoniae and Citrobacter freundii by morphological and biochemical tests. Citrobacter freundii showed the highest enzyme production of 19 milliunits/ $\mathrm{ml}$ after $36 \mathrm{hrs}$ of cultivation in $\mathrm{pH} 8$ phosphate buffer containing peptone. a-Galactosidase from Citrobacter freundii was purified by ammonium sulphate. fractionation and DEAE ion exchange chromatography. One a-galactosidase activity peak was observed indicating the presence of a single enzyme form. A 164 fold purification was obtained with a yield of $8 \%$. Polyacrylamide gel electrophoresis of the enzyme showed 2 protein bands. The kinetic properties of the enzyme were studied using p-nitrophenyl a-D-galactopyranoside. The Michaelis constant and maximum reaction velocity obtained were $2.85 \times 10^{-3} \mathrm{M}$ and $14 / \mathrm{mmol} / \mathrm{min} / \mathrm{mg}$ of protein respectively. Studies on the effect of $\mathrm{pH}$ on enzyme activity showed a broad $\mathrm{pH}$ optimum from 6.0 to 8.0 with maximum activity at $\mathrm{pH} 7.5$ at $29^{\circ} \mathrm{C}$. The enzyme was stable between $\mathrm{pH} 5.5$ to 8.0 . The optimum enzyme activity was observed at $40^{\circ} \mathrm{C}$ at pH 7.5. The enzyme was stable upto $40^{\circ} \mathrm{C}$. The enzyme preparation did not contain any invertase activity.
\end{abstract}

Key Words : Citrobacter freundii, Extracellular, $\alpha$ - Galactosidase, Kinetics.

\section{INTRODUCTION}

$\alpha$-Galactosidase ( $\alpha$-D-galactoside galactohydrolase) hydrolyses $\alpha-1,4$ galactosidic linkages of galactose containing polysaccharides. It has been reported to occur widely in microorganisms, plants and animals. This enzyme is used in industry and in medicine.

In Japan and in USA, the raffinose content in molasses of the beetsugar industry is reduced using $\alpha$-galactosidase by the addition of Mortierella vinacea mycelial pellets. ${ }^{1}$

Partially purified $\alpha$-galactosidase from Aspergillus sato ${ }^{2}$ and Cladosporium cladosporides $^{3}$ have been shown to be capable of removing flatulence causing oligosaccharides from soy milk.

In addition to these, this enzyme has been used in the pulp and paper industry ${ }^{4}$ and in the manufacture of gelling agents. ${ }^{5}$

\footnotetext{
${ }^{*}$ Corresponding author
} 
Microorganisms are the most promising sources for large scale enzyme production. They can be easily grown and it is usually not difficult to scale up the production process. With microbes, it is possible to increase the production by changes in the growth conditions.

In this paper, we report the partial purification of extracellular $\alpha$-galactosidase from Citrobacter freundii and kinetic studies carried out with the same enzyme preparation.

\section{METHODS AND MATERIALS}

Materials: Analytical grade Serva Fein Bicchemicals and Sigma Chemicals were used. DEAE Sephadex A-25 was obtained from Pharmacia Fine Chemicals.

Absorbance measurements were carried out using a Shimadzu UV 120-02 spectrophotometer. Bench centrifuge (MSE) and high speed centrifuge (Beckman Model J2-21) were used for centrifugation.

Enzyme Assay: To $1 \mathrm{ml}$ of culture supernatant, $1 \mathrm{ml}$ of $0.15 \mathrm{M} \mathrm{McIlvaine} \mathrm{buffer} \mathrm{(pH7.5)}$ was added and mixed well. $1 \mathrm{ml}$ of this mixture was incubated with $0.5 \mathrm{ml}$ of $1 \mathrm{mM}$ p-nitrophenyl $\alpha$-D-galactosidase (PNGP) solution for 30 minutes at $29^{\circ} \mathrm{C}$. The reaction was terminated by the addition of $5 \mathrm{ml}$ of $0.1 \mathrm{~N} \mathrm{Na}_{2} \mathrm{CO}_{3}$. Absorbance was measured at $405 \mathrm{~nm}^{6}$

A unit of enzyme activity is defined as the amount that hydrolyses $1 \mu$ mol of substrate per minute under specified conditions.

Protein Estimation: The protein determinations were done by the method of Lowry et $\mathrm{al}^{7}{ }^{\mathrm{i}}$ sing crystalline bovine serum albumin as standard.

Isolation of bacteria producing extracellular $\alpha$-galactosidase: Soil was incubated in a culture medium containing raffinose, peptone, yeast extract and salt solution. After incubation the bacteria present in the medium were isolated in pure form. These pure bacterial cultures were grown in the same culture medium and the supernatant was tested for $\alpha$-galactosidase activity. Three bacterial species that showed high enzyme production were identified as Escherichia coli, Klebsiella pneumoniae and Citrobacter freundii by morphological and biochemical tests. ${ }^{8}$

Citrobacter freundii gave the highest enzyme production of $14 \mathrm{mu} / \mathrm{ml}$ after $18 \mathrm{~h}$ of cultivation when grown in peptone culture medium with an initial $\mathrm{pH}$ of 8 . Extracellular $\alpha$-galactosidase production of Citrobacter freundii could be increased upto $19 \mathrm{mu} / \mathrm{ml}$ when cultivated ir: $\mathrm{pH} .8$ phosphate buffer culture medium for $36 \mathrm{~h} .^{8}$ 


\section{Purification of $\alpha$-galactosidase}

Extraction: The $\alpha$-galactosidase enzyme present in the culture medium was obtained by centrifugation of the culture broth at $5000 \mathrm{~g}$ at $4^{\circ} \mathrm{C}$ for 20 minutes. The supernatant was retained.

Ammonium Sulphate Fractionation: The supernatant was brought upto $75 \%$ $\left(\mathrm{NH}_{4}\right)_{2} \mathrm{SO}_{4}$ saturation using solid $\left(\mathrm{NH}_{4}\right)_{2} \mathrm{SO}_{4}$. The $75 \%$ saturated solution was centrifuged at $25000 \mathrm{~g}$ for 20 minutes at $4{ }^{\circ} \mathrm{C}$. The precipitate was dissolved in a minimum volume of $0.001 \mathrm{M}$ Mcllvaine buffer $(\mathrm{pH} 7)$ and dialysed with the same buffer.

DEAE Sephadex A-25 Ion Exchange Chromatography: A column of DEAE A-25 $(1.6 \mathrm{~cm} \times 40 \mathrm{~cm})$ was prepared as described by Andrews. ${ }^{9}$ The dialysed $\left(\mathrm{NH}_{4}\right)_{2} \mathrm{SO}_{4}$ fraction was applied and eluted with a 2:1 McIlvaine buffer containing $\mathrm{NaCl}$. The mixing chambers contain $100 \mathrm{ml}$ of $0.001 \mathrm{M}$ McIlvaine buffer ( $\mathrm{pH} 7$ ) (starting buffer) and $50 \mathrm{ml}$ of $0.1 \mathrm{M} \mathrm{McIlvaine} \mathrm{buffer}(\mathrm{pH} 7)$ containing $10 \% \mathrm{NaCl}$. Fractions (10ml) were collected in a refrigerated fraction collector at a flow rate of $1 \mathrm{ml} / \mathrm{min}$. (Figure 1) The fractions containing enzyme activity were pooled, dialysed and retained.

Polyacrylamide gel electrophoresis: (PAGE): PAGE was carried out by the method described by Weber \& Osborne ${ }^{10}$ using the Shandon apparatus. Polyacrylamide gels were prepared and loaded with $40 \mu \mathrm{l}$ of the enzyme preparation. 0.01M Phosphate buffer $\mathrm{pH} 8.0$ was used as the reservoir buffer. Gels were siained for prrteins using Coomassie blue.

The enzyme preparation was tested for invertase-activity using sucrose. ${ }^{2}$

Kinetic studies were carried out using PNGP as the substrate.

\section{RESULTS}

\section{Purification}

Purification of $\alpha$-galactosidase from Citrobacter freundii is summarized in Table 1. The multistep purification gave an overall yield of $8 \%$ and the $\alpha$-galactosidase was purified 164 fold. (Table 1). A high decrease in activity is observed in DEAE chromatography (Figure 1) indicating that the enzyme could be inactivated in solutions with a low protein concentration.

Test for purity: PAGE of the enzyme preparation gave two protein bands and one $\alpha$-galactosidase activity band. 
Table 1: Purification of $\alpha$ - Galactosidase from Citrobacter freundii spent culture medium.

\begin{tabular}{lcccccc}
\hline Purification stage & $\begin{array}{c}\text { Total } \\
\text { Volume } \\
(\mathrm{ml})\end{array}$ & $\begin{array}{c}\text { Total } \\
\text { Activity } \\
(\mathrm{mU})\end{array}$ & $\begin{array}{c}\text { Total } \\
\text { Protein } \\
(\mathrm{mg})\end{array}$ & $\begin{array}{c}\text { Specific } \\
\text { Activity } \\
(\mathrm{mU} / \mathrm{mg} \\
\text { Protein) }\end{array}$ & $\begin{array}{c}\text { Recovery } \\
(\%)\end{array}$ & $\begin{array}{c}\text { Purification } \\
\text { (fold) }\end{array}$ \\
\hline 5000g supernatant- SI & 2100 & 11603 & 2241 & 5 & 100 & 1 \\
$0-75 \%\left(\mathrm{NH}_{4}\right)_{2} \mathrm{SO}_{4}$ pellet-P11 260 & 9900 & 43.5 & 228 & 85 & 44 \\
Ion Exchange & 10 & 968 & 1.1 & 848 & 8 & 164 \\
Chromatography & & & & & & \\
DEAE-25 & & & & & & \\
\hline
\end{tabular}

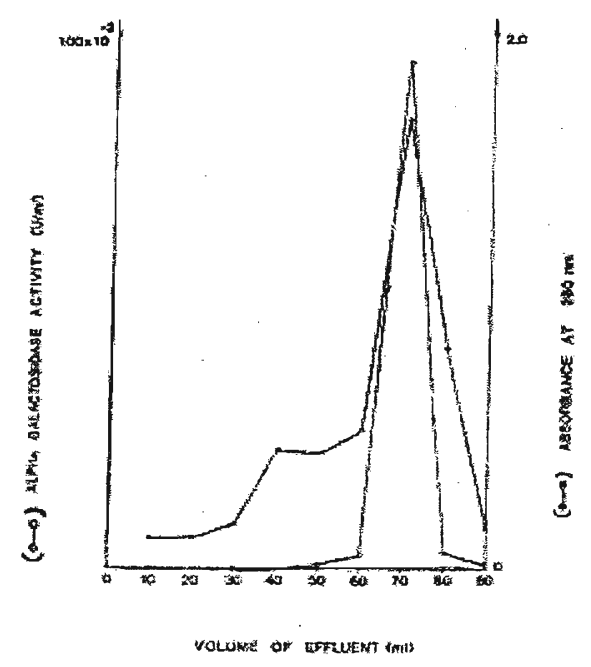

Figure 1: Fractionation of the partially purified alpha-galactosidase preparation (0-75\% ammonium sulphate fraction) from Citrobacter freundii on DEAE sephadex A-25.

The enzyme preparation did not display invertase activity

Effect of subtract concentration on enzyme activity: $\alpha$-Galactosidase was incubated at $29^{\circ} \mathrm{C}$ in (0.15M) McIlvaine buffer ( $\mathrm{pH} 7.5$ ) containing PNGP for $30 \mathrm{mins}$. The $\mathrm{Km}$ and Vmax values of $\alpha$-galactosidase for the substract determined from the linear part of the Lineweaver-Burk plot were $2.85 \times 10^{-3} \mathrm{M}$ and $14 \mu \mathrm{mol} / \mathrm{mg}$ of protein (Figure 2). No significant difference in $\mathrm{Km}$ and Vmax values were observed when $\mathrm{Km}$ and Vmax values were calculated by the Hofstee plot. 


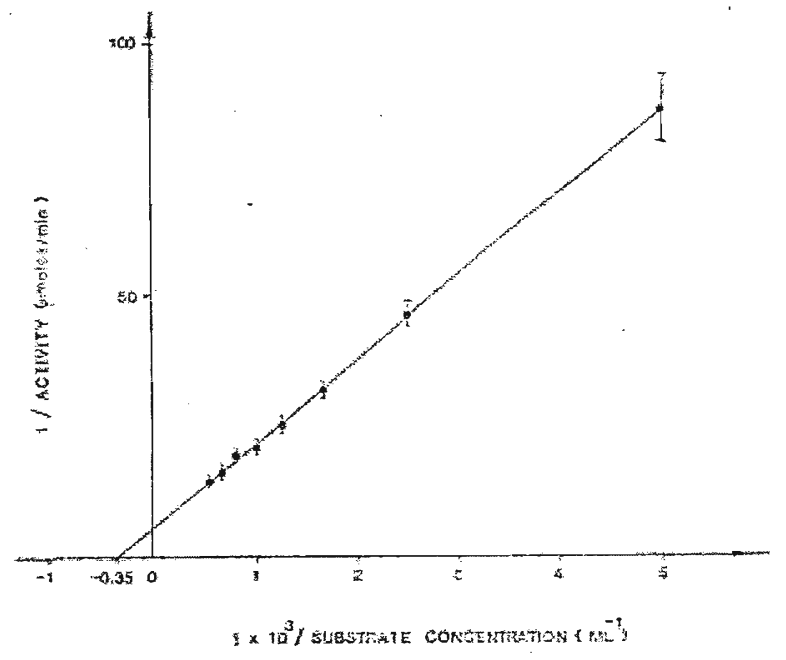

Figure 2: Lineweaver Burk double reciprocal plot for $\alpha$-galactosidase from Citrobacter freundii

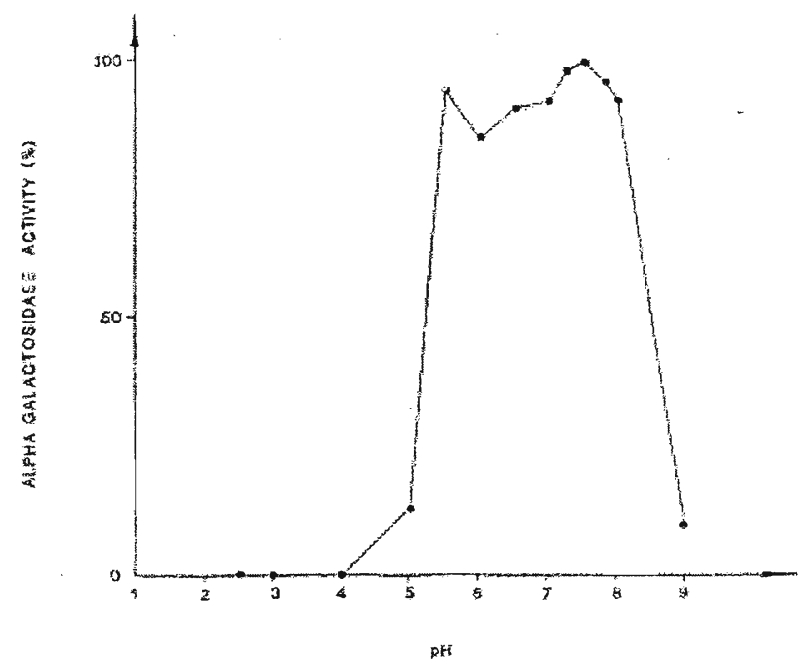

Figure 3: Effect of $\mathrm{pH}$ on the activity of alpha-galactosidase from Citrobacter freundii.

Effect of $p H$ on enzyme activity: $\alpha$-Galactosidase in (0.15M) McIlvaine buffer incubated for 30 minutes at $29^{\circ} \mathrm{C}$ showed high activity between $\mathrm{pH} 5.5$ to 8.0 with a maximum activity at $\mathrm{pH} 7.5$ (Figure 3 ).

Stability of the enzyme at different $p H$ values : The enzyme was incubated in $0.01 \mathrm{M}$ Mcllvaine buffer at $\mathrm{pH} 5.0,5.5,6.0,6.5,7.0,7.5,8.0,8.5$ at $29^{\circ} \mathrm{C}$ and assayed for activity at 1 hour intervals using $0.1 \mathrm{M}$ McIlvaine buffer $\left(\mathrm{pH} 7.5\right.$ ) at $29^{\circ} \mathrm{C}$. 
The enzyme is stable over a broad $\mathrm{pH}$ range of $6.0-8.0$. The enzyme is relatively less stable at low $\mathrm{pH}$ values than at high $\mathrm{pH}$ values (Figure 4).

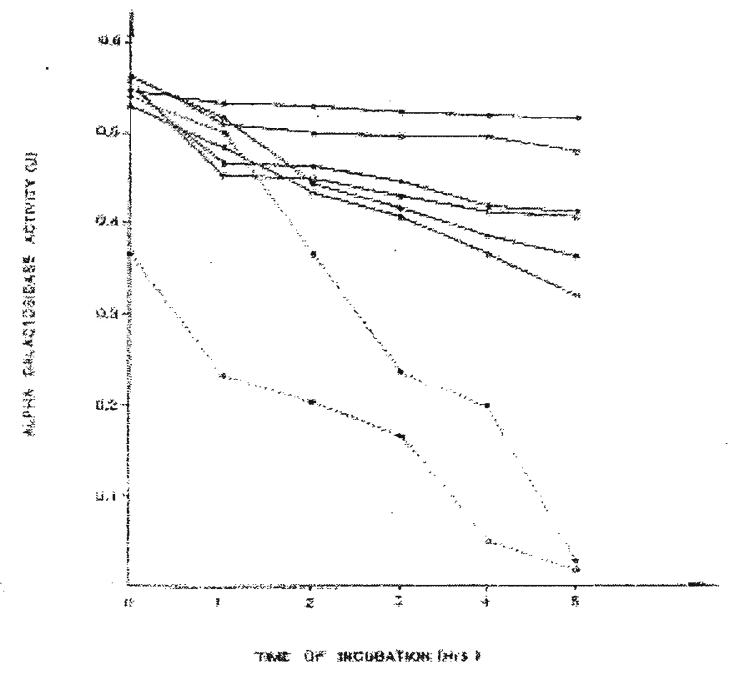

Figure 4: Effect of $\mathrm{pH}$ on the stability of alpha- galactosidase from Citrobacter freundii.

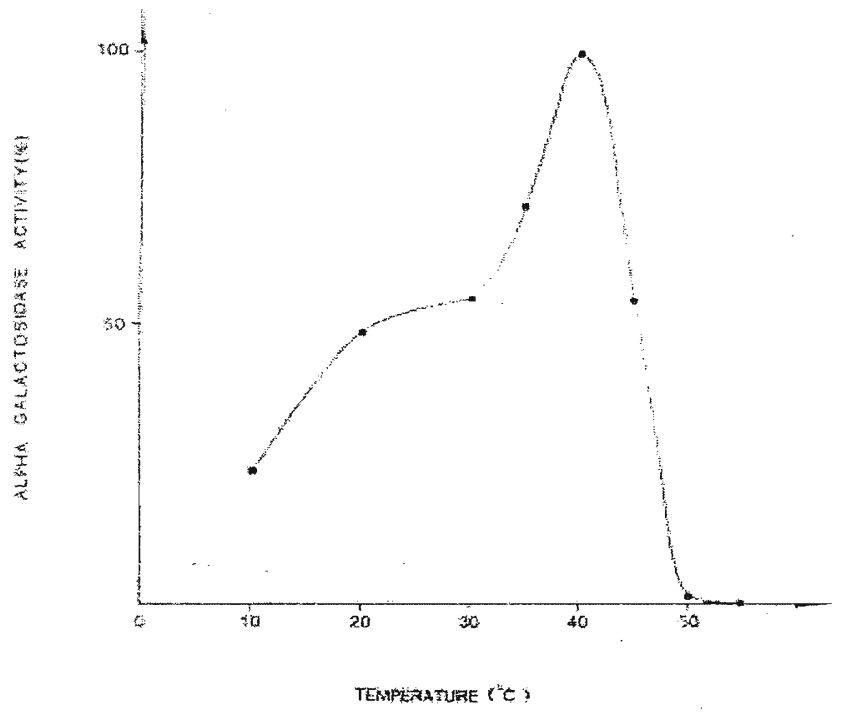

Figure 5: Effect of temperature on the stability of alpha- galactosidase from Citrobacter freundii. 


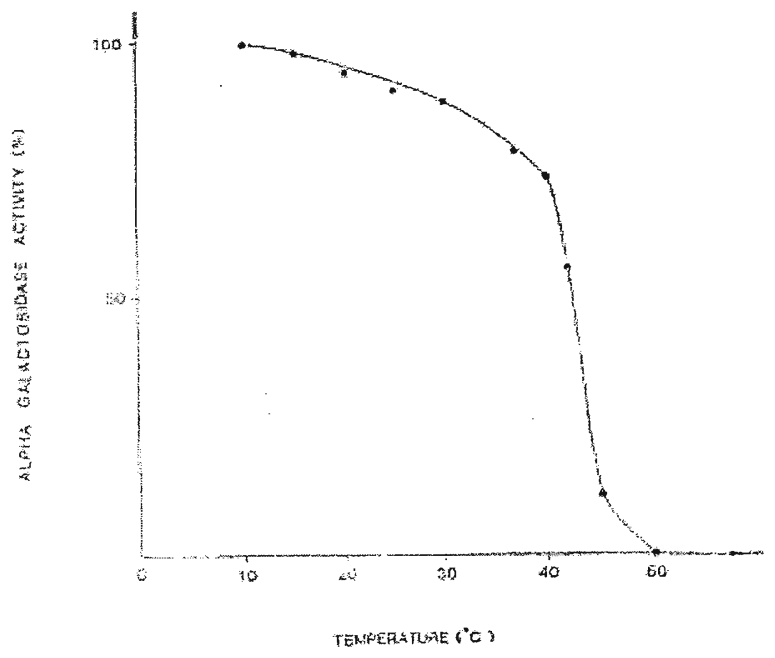

Figure 6: Effect of temperature on the stability of alpha-galactosidase from Citrobacter freundii.(incubated for $2 \mathrm{~h}$.)

Effect of temperature on enzyme activity: The enzyme when incubated at temperatures from $10^{\circ} \mathrm{C}$ to $50^{\circ} \mathrm{C}$ in $0.15 \mathrm{M}$ McIlvaine buffer ( $\mathrm{pH} 7.5$ ) for 30 minutes has an optimum activity at $40^{\circ} \mathrm{C}$. The activity of the enzyme increases with temperature from $10^{\circ} \mathrm{C}$ to $40^{\circ} \mathrm{C}$, thereafter it decreases with further increase in temperature. (Figure 5).

Stability of the enzyme at different temperatures: When incubated for 2 hours at temperatures varying from $10^{\circ} \mathrm{C}$ to $50^{\circ} \mathrm{C}$ in $0.15 \mathrm{M} \mathrm{Mcllvaine} \mathrm{buffer} \mathrm{(pH} \mathrm{7.5)} \mathrm{and}$ assayed for enzyme activity at $29{ }^{\circ} \mathrm{C}$ it was observed that the thermal stability of the enzyme gradually decreases upto $40^{\circ} \mathrm{C}$. It retained about $60 \%$ activity at $40^{\circ} \mathrm{C}$ (Figure 6). The enzyme lost almost $90 \%$ activity when incubated at $50^{\circ} \mathrm{C}$ for $30 \mathrm{mins}$.

\section{DISCUSSION}

$\alpha$-Galactosidase has been isolated from several bacterial species. Klebsiella sp.No.PG-211,E.coli sub sp.Communior IAM $1272^{12}$ and Bacillus stearothermophilus. ${ }^{13}$

Michaelis constant $(\mathrm{Km})$ for extracellular $\alpha$-galactosidase of $C$. freundii was less than the $\mathrm{Km}$ value obtained for intracellular $\alpha$-galactosidase of Klebsiella $\mathrm{sp}$ No. PG. $2^{11}$ for the same substrate indicating a higher affinity for the substrate.

$\alpha$-Galactosidase from plant ${ }^{14}$ and animal tissues ${ }^{15}$ have shown optimum $\mathrm{pH}$ in the acidic range 2.5-6.0. In the present investigation, $\alpha$-galactosidase from C. freundii appears to have a broad $\mathrm{pH}$ range from $5.5-8.0$ with a maximum activity at $\mathrm{pH}$ 7.5. A neutral $\alpha$-galactosidase activity has been reported in Klebsiella sp. No. PG $2^{11}$, E. coli, sub sp, communior IAM $1272^{12} \&$ B. stearothermophilus. ${ }^{13}$ 
$\alpha$-Galactosidase from Aspergillus niger ${ }^{16}$ is stable at $\mathrm{pH} 3.5-5.8 \alpha$-galactosidase from Trichoderma reesei RUTC- $30^{17}$ is stable at $\mathrm{pH}$ 4.5-6.5. Thus $\alpha$-galactosidase from $C$.freundii is stable over a broader $\mathrm{pH}$ range.

The optimum temperature of $40^{\circ} \mathrm{C}$, observed in the present study is higher than the optimum temperature reported from $\alpha$-galactosidase of E.coli ${ }^{12}$, Klebsiella sp. No. PG.2.11

The thermal stability of this enzyme is higher than $\alpha$-galactosidase from E.coli sp. Communior IAM $1272^{12}$, Klebsiella sp. ${ }^{11}$ and is relatively less than $\alpha$-galactosidase from B.stearothermophilus. ${ }^{13}$

$\alpha$-Galactosidase from $C$. freundii is extracellular and inducible in nature. In industry, extracellular enzymes are preferred. Most of the $\alpha$-galactosidase is optimally active at acidic $\mathrm{pH}$ values. In the sugar beet industry, low $\mathrm{pH}$ tends to cause inversion of sucrose or precipitation of proteins. Thus, it is important to have an enzyme with the optimum activity at $\mathrm{pH}$ 7.5. $\alpha$-Galactosidase from $C$. freundii is stable at room temperature and the enzyme solution does not contain invertase activity. A combination of $\alpha$-galactosidase and invertase activity results in an undesirable hydrolysis of raffinose to galactose.

\section{Acknowledgement}

The authors thank Prof. Jennifer Perera, Dept. of Microbiology, Faculty of Medicine, University of Colombo, for help in identifying the bacterial species.

\section{References}

1 Suzuli H., Ozawa Y., Ohta H. \& Yoshida H. (1969). Studies on the decomposition of raffinose by $\alpha$-galactosidase of mold: $\alpha$-galactosidase formation and hydrolysis of raffinose by the enzyme preparation. Agricultural and Biological Chemistry 33: 501-513.

2 Sugimoto H. \& Van B.J.P. (1970). Removal of oligosaccharides from soymilk by an enzyme from Aspergillus satoi. Journal of Food Science 35: 655.

3 Cruz R. \& Park Y.K. (1982). Production of fungal $\alpha$-galactosidase and its application to the hydrolysis of oligosaccharides in soybean milk. Journal of Food Science 47: 1973-5.

4 Talbot G. \& Sygusch T. (1990). Purification and characterization of thermostable $\beta$-mannase and $\alpha$-galactosidase from Bacillus stearothermophilus. Applied and Environmental Microbiology 56: 3505-3510. 
5 Mier H. \& Reid J.S.G. (1983). Reserve polysaccharides other than starch in higher plants. Encyclopaedia of Plant Physiology 418-471.

6 Dey P.M. (1969). Inhibition, transgalactosylation and mechanism of action of Sweet Almond $\alpha$-galactosidase. Biochemica et Biophysica Acta. 191: 644-652.

7 Lowry O. H, Rosebrough N. J, Farr A.L. \& Randall R.J. (1951). Protein measurements with the Folin phenol reagent. Journal of Biological Chemistry 193: $265-275$.

8 Lokuge M.A. \& Mathew C.D. (2000). Isolation from soil of bacteria producing extracellular $\alpha$-galactosidase. Journal of the National Science Foundation 28(4): 243-252.

9 Andrews P. (1964). Estimation of the molecular weight of proteins by sephadex gel-filtration. Biochemical Journal 92: 222-223.

10 Weber K. \& Osborn M. (1969). Journal of Biological Chemistry 244: 44064412.

11 Shah V. \& Parekh L.I. (1987). Purification and properties of $\alpha$-galactosidase from Klebsiella sp. No. PG.2. Indian Journal of Biochemistry and Biophysics 27: 103-7.

12 Kawamura S., Kasai T. \& Janusi S. (1976). Purification and properties of $\alpha$-galactosidase from Escherichía coli sub sp. Communior IAM 1272. Agricultural and Biological Chemistry 40: 641-8.

13 Delente J., Johnson J.H. Kuo M.J., O’Conner R.J. \& Weeks L.E. (1974). Production of a new thermostable natural $\alpha$-galactosidase from a strain of Bacillus stearothermophilus. Biochemistry and Bioengineering 16:1227-1243.

14 William J., Villarroya H. \& Petek F. (1977). Purification and properties of $\alpha$-galactosidase galactohydrolase from seeds of Trifolium repens (1977). Biochemical Journal 161: 509-515.

15 Beutler E. \& Kuhi W. (1972). Biochemical and electrophoretic studies of $\alpha$-galactosidase from normal man, in patients with Fabry's disease and in Equidae. American Journal of Human Genetics 24: 237-249.

16 Bahl O, N.P. \& Agrawal K.M.L. (1969). Glycosidases of Aspergillus niger Journal of Biological Chemistry 244: 2970-8. 
17 Zeilinger S., Kristufek D, Arisan A.T., Hodits R. \& Kubicek C.P. (1993). Conditions of formation, purification and characterization of an $\alpha$-galactosidase of Trichoderma reesei RUTC-30. Applied and Environmental Microbiology 59: $1347-1353$. 